\title{
The relationship between religious beliefs and coping with the stress of COVID-19
}

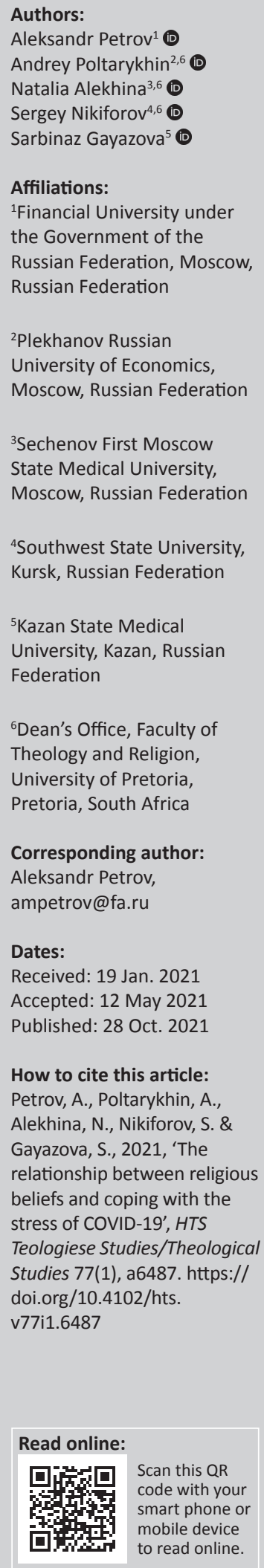

Recently, we have faced the outbreak of the coronavirus disease 2019 (COVID-19) in the world, which has attracted the attention of all people. Stress has become a word familiar to all people. The stressors of life are relatively clear and some of them cannot be eliminated by humans. One of the stressors in the life of humans is the COVID-19 pandemic. Doctors believe that the virus is controllable but its prevalence is quicker and deadlier than other viruses. In addition, the virus puts the elderly and those with underlying diseases (e.g. pulmonary problems) at extreme risk. Therefore, more care is seriously required to protect members of society. However, this psychological imbalance caused by the virus is associated with stress and anxiety. Lack of proper management of this stress will be associated with emotional impacts (e.g. depression and anxiety), physiological impacts (e.g. gastrointestinal disorders and increased heart rate), cognitive impacts (e.g. reduced concentration and distraction) and behavioural impact (e.g. increased work and activity avoidance, and sleep disorders).

Contribution: Given the importance of this topic, this study aimed to evaluate the relationship between religious beliefs and coping with COVID-19-related stress amongst Muslim students in three cities of Russia - Ingushetia, Chechnya and the Republic of Dagestan - in 2020. Data were collected using questionnaires, the validity and reliability of which were previously confirmed. According to the results, religious beliefs had an impact on stress coping by $p=$ 0.657 . In other words, students' ability to cope with stress improved by 0.657 units, with each unit of enhancement in their religious beliefs.

Keywords: religion; religious beliefs; Islam; coping with stress; COVID-19; Russia.

\section{Introduction}

A reality confirmed by scientific findings is that the secular community away from the pure essence of divine teachings is oriented towards increased diseases and mental and psychological stresses more than ever. In this regard, depression is one of the most common examples of these diseases (Sadeghian \& Heidarian Pour 2009). This is mainly important because various age groups and different lifestyles in the community deal with depression. However, this condition has different economic, social and cultural causes, roots and contexts. Today, it is revealed that stress is the primary factor affecting mental health (Gazder et al. 2014). In general, stress is the body's response to any demand, change or threat. Stress is not intrinsically good or bad but it might have positive or negative effects (Beddoe \& Murphy 2004). People's reaction to stressors is affected by cultural, religious and social factors and previous experiences largely (Rahman et al. 2013). In this regard, religion and religious beliefs play a key role in the prevention of psychological disorders. Religion is one of the most effective psychological supports, which saves the person from abeyance and meaninglessness in specific situations by providing explanatory support (Pourghane \& Khorsandi 2010).

It has been a while since a new variant of a known virus called the coronavirus disease 2019 (COVID-19) has drawn the attention of all people in the world. This virus has infected millions of people in the world and killed thousands of individuals so far. The virus has created psychological stress and fear amongst people. In this situation, psychological health along with individual and environmental hygiene should not be overlooked. However, the important issue is the fear of the effects of the virus, which can be more dangerous than the virus itself. In fact, people might be

Copyright: @ 2021. The Authors. Licensee: AOSIS. This work is licensed under the Creative Commons Attribution License.

Note: Special Collection: Faith Seeking Understanding, sub-edited by Seyed Mehdi Mousavi (Payame Noor University, Tehran, Iran) and the Dean's Office of the Faculty of Theology and Religion of the University of Pretoria. 
forced to pay more costs for treatment of damages caused by the fear of the virus over a longer period. According to numerous religious experts, religious beliefs play a vital role in the improvement of psychological health and stress management. According to these scholars, human nature always demands a connection to an external source for guidance (Vaillant et al. 2008). This support, which prevents several psychological damages, definitely affects the mental health of individuals. Because the outbreak of COVID-19 has contributed to public fear and panic amongst individuals, experts on religion and education have recommended taking refuge in one's religious beliefs to eliminate anxiety and achieve psychological tranquillity, thereby guaranteeing one's mental health.

Divine religions have proposed healthy approaches to be free of psychological pressure in life, adherence to which can guarantee and supply mental health (Forouhari et al. 2019). A result of these techniques is eliminating, as well as controlling and managing stress (Zhao et al. 2015). (1) Trust in God: man seeks peace in the face of adversity and trouble. In divine insight, trust in God is a way to deal with problems such as diseases. In fact, trust in God is a stable and unlimited parapet, which gives man hope and a sense of security and support. In many cases, trust in God has been recommended as a principle in dealing with problems. (2) Worship and prayer: asking for support is a method to cope with stress. Man has a God-seeking nature and seeks shelter in the refuge of God in moments of loneliness and panic. Those who have faith in God and afterlife believe that goodness and expediency exist behind events. Believing that God's goodness alone is absolute and God never wants anything bad for his servant, believers have patience against problems and diseases by saying prayers to God and achieve tranquillity and calmness by hoping that after a storm comes a calm. Therefore, the positive energy that comes from this type of thinking has a significant effect on their treatment process, especially during these days when the spread of this sinister virus has caused fear in all people.

Without a doubt, a person who believes in God and knows that everything is handled by God in the world considers strong belief and faith as the main factor for the complete resistance of problems (Koenig et al. 2012). They believe that God can solve any problem owing to his eternal power. These days, the fear and stress caused by COVID-19 have overcome everyone, and most people cannot manage their stress, which has led to their lack of calmness in life.

Man's attention to God is innate and internal (Hoff et al. 2008) and is not limited to a specific time and place. Whilst some people may go astray, it is generally known that man has internal attention to God, which is beyond time and space. Considering this issue, COVID-19 not only will have no negative impact on religious beliefs but also will deepen them as people, because it draws people's attention to a superior force. Evidence of this is the greater attention of people all over the world to spirituality (Shukla \& Rishi 2017). With the increased spread of COVID-19 in the world, this internal need of mankind for religious beliefs and spirituality will be increased as well, which could be recognised as one of the holy achievements of COVID-19. Despite various problems caused by the virus, including the death of loved ones and severe economic and social problems, which are definitely upsetting, more attention to spirituality is a divine gift. Therefore, executive officials of countries should make plans to maintain people's calm.

With regard to the importance of this topic, the present study aimed to evaluate the relationship between religious beliefs and coping with COVID19-related stress in Russia in 2020.

\section{Methods}

\section{Statistical population and sampling method}

The statistical population included 3500 Muslim students in three cities of Ingushetia, Chechnya and Republic of Dagestan. The sample size was estimated at 246 based on the Krejcie and Morgan table (1970), and the participants were selected by convenience sampling. In total, 275 questionnaires were distributed amongst the students, 263 of which were completed properly and the rest were eliminated from the research. The data collection tool was a 30-item questionnaire, which encompassed 15 items about religious beliefs and one item about students' level of stress (Appendix 1). It is worth noting that the items were scored based on a five-point Likert scale ranging from 1 (completely disagree) to 5 (completely agree). Amongst these, $68 \%$ were men and $32 \%$ were women. In addition, $29 \%$ of people were under 15 years old, 36\% were between 15 and 25 years old and 35\% of them were over 25 years old.

\section{Reliability and validity of the questionnaire}

Content validity was applied to evaluate the validity of the self-administered questionnaire. To this end, the tool was provided to 10 faculty members who had conducted several similar scientific studies. These scholars reviewed the items of the questionnaire and provided recommendations to make the text of the tool more comprehensible. Finally, they confirmed the generality of the questionnaire. Moreover, the reliability of the tool was confirmed by distributing 30 questionnaires amongst the statistical samples and using Cronbach's alpha in Statistical Package for the Social Sciences (SPSS) (see Table 1).

The reliability of the tools was confirmed at a Cronbach's alpha of 0.7 (Cronbach 1951). Cronbach's alpha coefficient was invented by Cronbach in 1951 and is one of the most common methods of measuring the reliability of questionnaires. Cronbach's alpha coefficient is used to measure the one-

TABLE 1: Cronbach's alpha of the questionnaire.

\begin{tabular}{lcc}
\hline Variables/components & Number of items & Cronbach's alpha \\
\hline Religious beliefs & 15 & 0.83 \\
Coping with stress & 15 & 0.82 \\
\hline Total questionnaire & 30 & 0.88 \\
\hline
\end{tabular}


dimensionality of attitudes, judgements, beliefs and other categories that are not easy to measure. In fact, we want to see to what extent the respondents' perceptions of the questions were the same. The basis of Cronbach's alpha coefficient is also the basis of spectra or scales.

Furthermore, SPSS was used to analyse the theoretical framework of the research and estimate the impact coefficient. To this end, the normality of the data was first assessed by the Kolmogorov-Smirnov test, followed by the use of Pearson's correlation coefficient to evaluate the relationship amongst the variables. With the help of this test, it is possible to determine with a random sample of the statistical population whether the statistical population follows the desired distribution or not. Furthermore, with this test, it is possible to examine the all-distribution between the two communities.

\section{Findings}

Table 2 shows the results of the Kolmogorov-Smirnov test. According to the table, variables with a level of significance above 0.05 had a normal distribution. Normal data allow the use of parametric tests in the statistical analysis process. The relationship between the variables is assessed below.

Hypothesis 1: there is a significant relationship between religious beliefs and coping with stress.

$\boldsymbol{H}_{\mathbf{0}}: r=0$

$\boldsymbol{H}_{1}: r \neq 0$

It is noteworthy that by analysing the obtained data that measure different aspects of religious beliefs and coping with stress, according to George and Mallery (2019), the correlation coefficient test shows the final relationship between the two main variables of the research. According to Table 3, the relationship between the variables was statistically significant because the significance level (sig = $0.000)$ was lower than the predicted error level $(\alpha=0.05)$. In addition, the $\mathrm{H}_{0}$ and $\mathrm{H}_{1}$ were rejected and confirmed, respectively, considering that the correlation coefficient was reported to be 0.657 . Therefore, at a $95 \%$ confidence interval, there was a significant and direct relationship between religious beliefs and coping with stress. In other words, improvement of religious beliefs led to a higher ability to cope with COVID19-related stress in students. Moreover, the $t$-test of a statistical community (mean) was applied in the present study to assess the status of each of the research variables in the evaluated society. According to Landau and Everitt (2004:38), the one-sample $t$-test is to determine whether an unknown population mean is different from a specific (common or standard) value or even a case. In this test, a mean value above the contractual value of three (the moderate value) is favourable. It is notable that the test was implemented in SPSS. The test

TABLE 2: Kolmogorov-Smirnov test.

\begin{tabular}{lccl}
\hline Variables & K-S statistic value & Level of significance & Results \\
\hline Religious beliefs & 0.876 & 0.764 & Normal \\
Coping with stress & 0.754 & 0.563 & Normal \\
\hline
\end{tabular}

determines the status of each research variable, according to which recommendations can be made to improve the variables. Table 4 shows the results of the one-sample $t$-test.

It should be noted that the averages of the variables of religious beliefs and coping with stress of COVID-19 have been calculated in such a way that the averages of the 15 components for each variable in the research questionnaire that measures different aspects of variables have been calculated by the SPSS software and the final result in the form of a single number that represents the final variable is listed in Table 4. All values had a significance level of less than 0.05 at the level of analysis of research variables. The values of these variables were above the moderate value of community because of the positive $\mathrm{T}$ statistic. Therefore, their status was reported to be appropriate. It could be expressed that the value of these variables was more than the mean value of society and their status was estimated to be appropriate.

\section{Implications and recommendations}

As discussed in the present study, religious beliefs play a fundamental role in the management of anxiety and stress. It is important to note that human nature also demands a connection to an external source for guidance. Given the unsought COVID-19 outbreak and excessive fear and anxiety in human beings caused by this incident, religious experts recommend us to take refuge in our religious beliefs to manage and cope with stress. Nonetheless, accepting or rejecting this claim of religious experts requires field research in order to assess the relationship between religious beliefs and coping with stress. Therefore, the present study mainly focused on this topic.

Given the importance and priority of prevention of diseases and recommendations given by Islamic teachings about treatment methods, it is hoped that effective steps are taken towards decreasing diseases, especially incurable diseases, by applying Islamic teachings. In Islam, which is a comprehensive religion, some points are made about how to be free of life stresses, adherence to which can supply and guarantee mental health. As a result, humans can easily cope with their stress and properly manage it. Without a doubt, believing in God and the fact that all affairs of the world are managed by God will result in having a firm belief in God's ability to deal with any problem in life. People who trust in God believe that God solves any problem owing to his eternal power. As such, humanity (especially Muslims; as the results of this study showed) should know by nature that there is an endpoint in life, which cannot be responded to by nature, and there is a need for supernatural power, which is God Almighty.

TABLE 3: Pearson test results to assess the first hypothesis.

\begin{tabular}{lcccc}
\hline Variables & $\begin{array}{c}\text { Number of } \\
\text { samples }\end{array}$ & $\begin{array}{c}\text { Correlation } \\
\text { coefficient }\end{array}$ & Error rate & $\begin{array}{c}\text { Level of } \\
\text { significance }\end{array}$ \\
\hline $\begin{array}{l}\text { Religious beliefs } \rightarrow \text { coping } \\
\text { with stress }\end{array}$ & 263 & 0.657 & 0.05 & 0.000 \\
\hline
\end{tabular}


TABLE 4: The one-sample $t$-test.

\begin{tabular}{lccccccc}
\hline Variable & Mean & Standard deviation & $\boldsymbol{T}$ - Statistic & Degree of freedom & Significance & Mean difference & Status \\
\hline Religious beliefs & 3.96 & 0.423 & 21.40 & 262 & 0.000 & 1.04 & Appropriate \\
Coping with stress & 3.92 & 0.484 & 21.23 & 262 & 0.000 & 1.08 \\
\hline
\end{tabular}

According to the results of the present study, religious beliefs affected stress coping by $p=0.657$. In other words, improved religious beliefs result in a better ability to cope with stress in people (Table 3). In addition, the Muslim students in the three cities of Ingushetia, Chechnya and Republic of Dagestan had an acceptable level of religious beliefs (mean $=3.96$ ), which could be the cause of their great ability to cope with stress $($ mean $=3.92)$.

These days, the COVID-19 outbreak has caused public panic and stress, and it could be mentioned that most people have failed to manage their stress. In other words, the virus has disturbed public peace. In this respect, some prayers have been recommended to return peace to people's lives and pass this crisis safely with the help of God and collective participation. For example, Surah Ghafir, Ayat 60: Your Lord has said, 'Call Me, and I will hear you'! Indeed those who are disdainful of my worship will enter hell in utter humiliation. And in Surah Al-Baqarah, Ayat 186: When My servants ask you about Me, [tell them that] I am indeed nearmost. I answer the supplicant's call when he calls Me. So let them respond to $\mathrm{Me}$, and let them have faith in Me, so that they may fare rightly. And in Surah Al-Anbya, Ayat 87: And [remember] the Man of the Fish, when he left in a rage, thinking that we would not put him to hardship. Then he cried out in the darkness, 'There is no god except You! You are immaculate! I have indeed been among the wrongdoers'! Moreover, the Quran includes miracles throughout its material and spiritual life, and we will definitely see its signs if we read it with wisdom. However, the most miraculous effects mentioned in the Quran are found in Surah Al Hamd, which is a prescription for treating all mental and physical ailments of humanity. It is: In the name of God, Most Gracious, Most Merciful * Praise be to God, Lord of the universe * Most Gracious, Most Merciful * Master of the day of judgment * we worship you only, We ask you for help only * Guide us in the right path * The path of those whom you blessed, not of those who have deserved wrath, nor of the strayers.

The easiest treatment and the least expensive treatment for any disease is reciting Surah Al Hamd. The Holy Prophet said $(\mathrm{PBUH})$ : Surah $\mathrm{Al}$ Hamd was not recited for any pain unless the pain subsided (The Holy Quran/Surah Al Hamd).

\section{Conclusion}

The mentioned suggestions are effective in eliminating stress and providing peace to people. We can defeat the stress of COVID-19 by being inspired by Islamic teachings and religious beliefs, as concluded by the results of the current study. It is noteworthy that all healthcare specialists and experts, as well as officials and authorities of countries, emphasise staying home and adhering to hygiene protocols. Evidently, psychologists' strategies are also fundamentally important in managing the stress of the COVID-19 pandemic. Nevertheless, considering the results of the present study, and given the fact that human nature leans toward spirituality and religious beliefs to achieve peace, it is best to encounter with God and apply religious orders along with health instructions in order to provide physical health and improve the spiritual strength of human beings in these stressful times. This study deals with the relationship between religious beliefs in an Islamic society and coping with stress, and the results are presented. It is worthwhile for other researchers to present their research studies in different societies and expand the results of the present study.

\section{Acknowledgements Competing interests}

The authors declare that they have no financial or personal relationships that may have inappropriately influenced them in writing this article.

\section{Authors' contributions}

All authors contributed equally to the writing of this article.

\section{Ethical considerations}

This article followed all ethical standards for research without direct contact with human or animal subjects.

\section{Funding information}

This research received no specific grant from any funding agency in the public, commercial or not-for-profit sectors.

\section{Data availability}

Data sharing is not applicable to this article as no new data were created or analysed in this study.

\section{Disclaimer}

The views and opinions expressed in this article are those of the authors and do not necessarily reflect the official policy or position of any affiliated agency of the authors.

\section{References}

Beddoe, A.E. \& Murphy, S.O., 2004, 'Does mindfulness decrease stress and foster empathy among nursing students?', Journal of Nursing Education 43(7), 305-312. https://doi.org/10.3928/01484834-20040701-07

Cronbach, L.J., 1951, 'Coefficient alpha and the internal structure of tests', Psychometrika 16(1), 297-334. https://doi.org/10.1007/BF02310555

Forouhari, S., Teshnizi, S.H., Ehrampoush, M.H., Mahmoodabad, S.S.M. Fallahzadeh, H., Tabei, S.Z. et al., 2019, 'Relationship between religious orientation, anxiety, and depression among college students: A systematic review and meta-analysis', Iranian Journal of Public Health 48(1), 43. https://doi. org/10.18502/ijph.v48i1.781 
Gazder, D.P., Ali, A.A., Naqvi, D.F., Zehra, N., Memon, I. \& Rafay, A., 2014, 'Recognition of stressors in postgraduate students of a teaching University in Pakistan', Education in Medicine Journal 6(4), 40-47. https://doi.org/10.5959/eimj.v6i4.276

George, D. \& Mallery, P., 2019, IBM SPSS Statistics 26 step by step a simple guide and reference, Routledge, London.

Hoff, A., Johannessen-Henry, C.T., Ross, L., Hvidt, N.C. \& Johansen, C., 2008, 'Religion and reduced cancer risk - What is the explanation? A review', European Journal of Cancer 44(17), 2573-2579. https://doi.org/10.1016/j.ejca.2008.08.001

Koenig, H., Koenig, H.G., King, D. \& Carson, V.B., 2012, Handbook of religion and health, Oxford University Press, Oxford.

Krejcie, R.V. \& Morgan, D.W., 1970, 'Determining sample size for research activities', Educational and Psychological Measurement 30(3), 607-610. https://doi. org/10.1177/001316447003000308

Landau, S. \& Everitt, B.S., 2004, A handbook of statistical analyses using SPSS, Chapman \& Hall, London.

Pourghane, P. \& Khorsandi, M., 2010, 'Survey the effect of religious beliefs in stress reduction in students of Langroud Faculty of Medical Sciences', Journal of Holistic Nursing and Midwifery 20(1), 10-15.
Rahman, A.A., Al Hashim, B.N., Al Hiji, N.K. \& Al-Abbad, Z., 2013, 'Stress among medical Saudi students at college of medicine, King Faisal University', Journal of Preventive Medicine and Hygiene 54(4), 195.

Sadeghian, E. \& Heidarian Pour, A., 2009, 'Stressors and mental health status among students of Hamadan University of Medical Sciences', Journal of Hayat 15(1), 71-80.

Shukla, P. \& Rishi, P., 2017, 'A correlational study of psychosocial \& spiritual wellbeing and death anxiety among advanced stage cancer patients', American Journal of Applied Psychology 2(3), 59-65. https://doi.org/10.1007/s12646017-0385-y

Vaillant, G., Templeton, J., Ardelt, M. \& Meyer, S.E., 2008, 'The natural history of male mental health: Health and religious involvement', Social Science \& Medicine 66(2), 221-231. https://doi.org/10.1016/j.socscimed.2007.09.011

Zhao, F.F., Lei, X.L., He, W., Gu, Y.H. \& Li, D.W., 2015, 'The study of perceived stress, coping strategy and self-efficacy of Chinese undergraduate nursing students in clinical practice', International Journal of Nursing Practice 21(4), 401-409. https:// doi.org/10.1111/ijn.12273 


\section{Appendix 1}

\section{5 items for religious beliefs}

The items were scored based on a five-point Likert scale from one (completely disagree) to five (completely agree).

1. I feel close to God.

2. I believe in Islamic teachings.

3. I am not disappointed as I believe in God.

4. Quran is a guide for life.

5. Islam is a comprehensive religion for humanity.

6. I participate in religious ceremonies.

7. I use Islamic teachings in all areas of life.

8. I read the Quran usually.

9. I pray to God every day.

10. I help poor people.

11. I avoid activities that are forbidden in Islam.

12. I attend mosques when possible.

13. If healthy, I fast during the Ramadan.

14. I respect people, especially the elderly.

15. I take the lead in doing good activities.

\section{5 items for coping with stress}

1. I always have faith in God in facing obstacles.

2. When I face problems, I try to be focused.

3. I try to manage stress.

4. I try to achieve my aims even if there are obstacles.

5. I do not give up when I face difficulties.

6. I can find help in complicated situations.

7. I can think clearly under pressure.

8. I may not be discouraged easily.

9. I am a strong person when dealing with challenges.

10. I can make difficult decisions.

11. I am able to handle unpleasant events.

12. I try to dedicate myself to change.

13. I have confidence in my ability.

14. In the face of difficulties, I believe in God's help.

15. There is a small amount of stress in me that motivates me to overcome problems. 